\title{
EFFECT OF NITROGEN ON THE METABOLIC ENZYME ACTIVITY OF LEAVES, PROTEIN CONTENT AND YIELD OF SORGHUM (SORGHUM BICOLOR [L.] MOENCH) IN NORTHERN CHINA
}

\author{
YANG, G. D. ${ }^{1}{ }^{*}-$ HU, Z. Y. ${ }^{1}-$ HAO, Z. Y. ${ }^{1}-$ LI, J. H. ${ }^{1}-$ WANG, Q. ${ }^{2}-$ MENG, X. X. ${ }^{2}-$ ZHOU, Y. F. ${ }^{3}$ \\ - HUANG, R. D. ${ }^{3}$ \\ ${ }^{1}$ Keshan Branch of Heilongjiang Academy of Agricultural Sciences, 161005 Heilongjiang, China \\ ${ }^{2}$ Crop Resources Institute of Heilongjiang Academy of Agricultural Sciences, 150086 \\ Heilongjiang, China \\ ${ }^{3}$ College of Agronomy, Shenyang Agricultural University, No. 120 Dongling Road, Shenyang, \\ 110866 Liaoning, China
}

The first two authors contributed equally to this paper

*Corresponding author

e-mail: ygdhouzhe2000@163.com

(Received 25 $5^{\text {th }}$ Jan 2021; accepted $14^{\text {th }}$ May 2021)

\begin{abstract}
With the improvement of breeding level and mechanization, sorghum planting has achieved the transformation from high-stalk and rare-planting to dwarf and high-density planting in China, but there are few reports on dwarf sorghum under high-density planting condition. Therefore, the aim of this work was to study the effect of different nitrogen doses $\left(0,100,200\right.$ and $300 \mathrm{~kg}$ of nitrogen ha $\left.{ }^{-1}\right)$ on its metabolic enzyme activity, the leaf area and Chlorophyll, so as to explore changes of yield and protein content of dwarf sorghum under the high-density planting management in northern China. The results of the two-year trials indicated that chlorophyll content, leaf area and the activity of nitrate reductase (NR) and glutamine synthetase (GS) were positively correlated with yield and protein, $200 \mathrm{~kg}$ of nitrogen $\mathrm{ha}^{-1}$ as the best rate, promoted metabolism enzyme activity, raised leaf area and chlorophyll content, and ensured the highest yield and protein content.
\end{abstract}

Keywords: sorghum, nitrogen fertilizer, yield, enzyme, high-density planting

\section{Introduction}

Sorghum bicolor (L.) Moench is the main food and economic crop in arid and semiarid areas and is widely used in feed, brewing, energy, food processing and other fields (Wang et al., 2015). Nitrogen (N) is a vital component required for the synthesis of chlorophyll and photosynthetic enzymes, which impact the photosynthesis of crops, its application can determine the overall yields of crops (Kaur et al., 2015). In plants, photosynthetic capability and nitrogen metabolism are closely related. Approximately $25 \%$ of the energy generated by photosynthesis can be used for nitrate reduction (Khripach et al., 2000; Beevers and Hageman, 1969; Giagnoni et al., 2016). Nitrate is mainly assimilated in plant leaves. The activity of NR is modulated by the photosynthetic electron transport chain (Chow et al., 2015).

At the same time, nitrogen is one of the most important elements in the process of carbon and nitrogen metabolism. NR, glutamate Synthase (GOGAT), GS and glutamate dehydrogenase (GLDH) are the main enzymes that affect nitrogen metabolism, their activity is closely related to soil fertility (Tischne, 2000; Singletary et al., 1990; 
Singaram and Kamalakumari, 2000). The utilization of nitrogen in crops involves the assimilation, transport and reuse of the absorbed nitrogen, in which the assimilating enzymes NR, GS and GOGAT play a key role. Inorganic nitrogen absorbed by sorghum must be assimilated by the plant, and further synthetized into amino acids, proteins and other substances necessary for the organism (Bingham et al., 2012). NR is the first enzyme in the process of nitrogen reduction, the presence of nitrate will promote the activity of NR (Nath and Tuteja, 2016; Lu et al., 2009). GS/GOGAT pathway is the most important pathway for further assimilation of ammonia under normal conditions (Zheng, 2009; Lea and Miflin, 2003).

The catalytic glutamine continues to generate glutamic acid by GOGAT, which involves carbohydrate assimilation and is the key node of carbon nitrogen interaction (Lea and Miflin, 2003). The seed weight increased after overexpression of GOGAT gene in rice, and pointed out that GOGAT played an important role in grain filling (Yamaya et al., 2002). Previous studies on corn (Presterl et al., 2010), wheat (Han et al., 2007; Xiong et al., 2016), rice (Zeng et al., 2007) and other crops showed that NR and GS activities of plants decreased under low nitrogen, but there were differences among different crops. The application of $\mathrm{N}$ can be conducive towards the enhancement of the drought resistance of crops by protecting photosynthetic apparatus, activating antioxidant defense systems, and improving osmoregulation, affecting growth and $\mathrm{N}$ metabolism (Gou et al., 2017). Most crops require $\mathrm{N}$ within an appropriate range that optimally aligns with their physiological requirements, the excessive application of $\mathrm{N}$ results in decreased crop yields (Jin et al., 2012). Methods to limit the negative impact of agricultural practices and increasing crop production sustainability has been one of the key agricultural challenges (Ronga et al., 2019; Tilman et al., 2011).

In recent years, sorghum has undergone a transformation from traditional tall-stalk and rare-planting to dwarf and high-density planting (Wang et al., 2011), The height of the main sorghum varieties in the north of Heilongjiang province are between 1.0 and $1.3 \mathrm{~m}$, and the planting density is between $20-35 \times 10^{4}$ plants/ha (Yang et al., 2015; Shen et al., 2013), which is the area with the largest sorghum production density in China. To the authors' knowledge, the research on dwarf sorghum under high-density planting management was still in a blank stage. In this paper, Keza15, a density-tolerant dwarf sorghum variety, was used as the experimental material. Through the study on the relationships between nitrogen and nitrogen metabolism enzyme activity, the leaf area, Chlorophyll, the regularity of yield and quality formation of high-density cultivation was expounded. It has a great significance to improve the efficiency of nitrogen utilization, to lay a foundation for the reasonable application of nitrogen fertilizer to dwarf sorghum under high-density planting condition.

\section{Materials and methods}

\section{Trial materials}

Keza15 was obtained from the Keshan branch of the Heilongjiang Academy of Agricultural Sciences (Qiqihar City, Heilongjiang Province, China).

Note: Keza15 was a density-tolerant brewing sorghum hybrid variety, plant height was approximately $100 \mathrm{~cm}$, panicle length was $26.5 \mathrm{~cm}$, the seeds produced reddishbrown oval-shaped grains. Optimal planting density was 300 thousand plants/hectare (Fig. 1). 


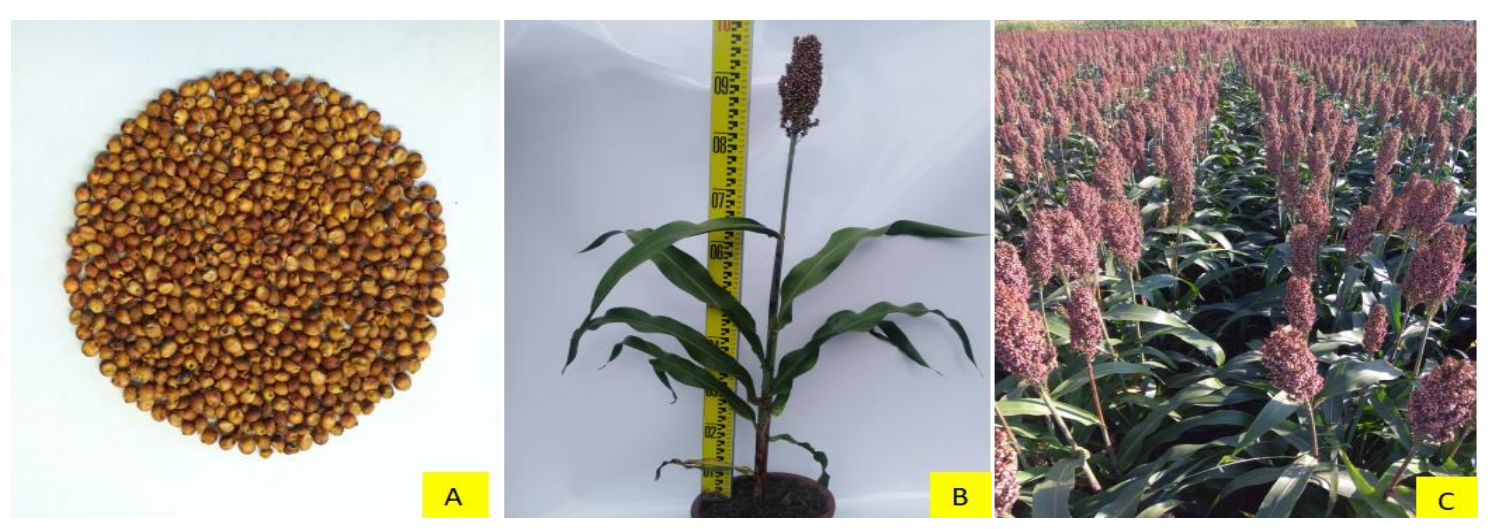

Figure 1. Morphological characteristics of Keza15. (A) Seeds, (B) plant, (C) group

\section{Trial conditions}

Field experiments were conducted in an open field at Keshan Branch of Heilongjiang Academy of Agricultural Sciences $\left(48^{\circ} 03^{\prime} 47^{\prime \prime} \mathrm{N}, 1^{2} 5^{\circ} 87^{\prime} 57^{\prime \prime} \mathrm{E}\right)$ (Qiqihar City, Heilongjiang Province, China), the experimental soil was a chernozem. The $0-20 \mathrm{~cm}$ soil in the plow layer had the following characteristics: organic matter $3.2 \times 10^{4} \mathrm{mg} \cdot \mathrm{kg}^{-1}$, $\mathrm{pH}$ 6.12, alkali hydrolyzed nitrogen $173 \mathrm{mg} \cdot \mathrm{kg}^{-1}$, available phosphorus $28.8 \mathrm{mg} \cdot \mathrm{kg}^{-1}$ and available potassium $307.2 \mathrm{mg} \cdot \mathrm{kg}^{-1}$. The region has a mid-temperate continental monsoon climate, The mean maximum and minimum air temperatures and total rainfall during the cropping cycles (May to September) were 29 and $8.3{ }^{\circ} \mathrm{C}$ and $316.5 \mathrm{~mm}$ for the year 2016 and 29.3 and $7.8{ }^{\circ} \mathrm{C}$ and $357.4 \mathrm{~mm}$ for the year 2017, respectively (Fig. 2).

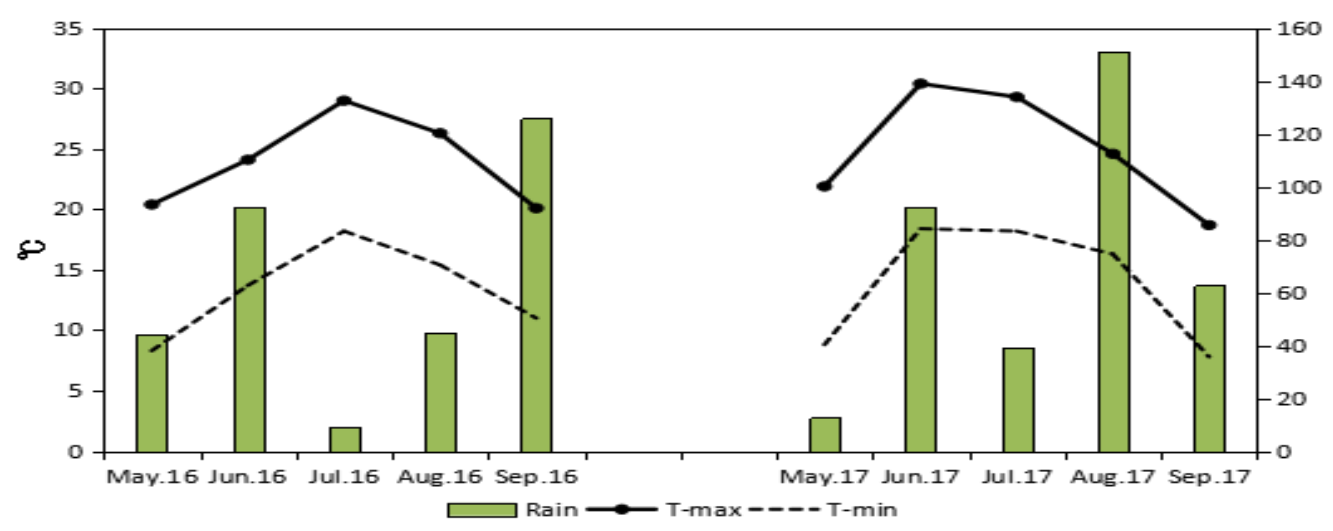

Figure 2. The mean maximum and minimum air temperatures and total rainfall during the cropping cycles (May to September) recorded in the two growing seasons (2016 and 2017)

Four nitrogen treatments were set up, and urea was used as the nitrogen source: $0 \mathrm{~kg}$ (N0), $100 \mathrm{~kg}(\mathrm{~N} 100), 200 \mathrm{~kg}(\mathrm{~N} 200)$ and $300 \mathrm{~kg}$ (N300) of pure nitrogen per hectare in both years.; nitrogen, $\mathrm{P}$ and $\mathrm{K}\left(\mathrm{P}_{2} \mathrm{O}_{5} 150 \mathrm{~kg}\right.$ and $\mathrm{K}_{2} \mathrm{O} 100 \mathrm{~kg}$ per hectare) were applied as seed fertilizer at one time. A randomized block design was used in the experiment with three repetitions. Every experiment repetition was $10 \mathrm{~m}$ long, consisting of eight rows with a $0.65 \mathrm{~m}$ ridge distance and 300,000 seedlings per hectare, and the management was the same as that of the general production fields. 


\section{Sample handling}

Plants of growth uniformity were selected as markers, and the samples were taken at Jointing stage, Flag leaf stage, Loose powder period, Grain filling stage, and at Max mature period.

\section{Determination of leaf area}

The leaf area was measured with a CI-203 handheld laser leaf area meter (CID, Inc., Camas, Washington USA).

\section{Determination of chlorophyll}

The method of the determination of chlorophyll content was referred to the modified method cited (Wang, 2006). The following formulas were used to calculate the content of photosynthetic pigments, in which $\mathrm{V}$ and $\mathrm{W}$ indicated the volume of extracting liquid $(\mathrm{ml})$ and the weight of material $(\mathrm{g})$.

$$
\begin{aligned}
& \text { Chlorophyl a }(\mathrm{Ca}) / \mathrm{mg} \cdot \mathrm{g}^{-1}=\left(12.21 \mathrm{~A}_{663}-2.81 \mathrm{~A}_{646}\right) \mathrm{V} /(1000 \times \mathrm{W}) \\
& \text { Chlorophy } \mathbf{l} \mathrm{b}(\mathrm{Cb}) / \mathrm{mg} \cdot \mathrm{g}^{-1}=\left(20.13 \mathrm{~A}_{646}-5.03 \mathrm{~A}_{663}\right) \mathrm{V} /(1000 \times \mathrm{W}) \\
& \text { Chlorophy } \mathbf{l}=\text { Chlorophyl } \mathrm{a}+\text { Chlorophy } \mathbf{l} \mathrm{b}
\end{aligned}
$$

\section{Determination of nitrogen metabolism related enzyme activity}

The activity of NR, GS, GOGAT and GLDH was determined by enzyme-linked immunosorbent assay. The kit was provided by Shanghai Enzyme-linked Biology Co., Ltd. (Shanghai, China), and the determination method was carried out according to the instructions.

\section{Yield measurement}

Grain yield and its composition: 20 plants were selected for yield determination. The indices included single ear weight, grain number per ear and thousand kernel weight. The yield was converted by the weight at $14 \%$ water content.

\section{Quality measurement}

Protein content was measured with a Near infrared quality analyzer (perten DA7200, Swedish).

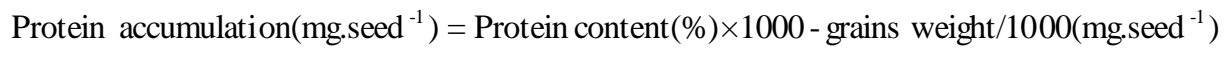

\section{Analysis software and analysis method}

The data were processed by Excel 2013 and were analyzed by SPSS 16.0. Analysis of variance was performed with SPSS 16.0 software, and data from each sampling data were analyzed separately. Means were tested by least significant difference at the $\mathrm{P}<0.05$ level. 


\section{Results}

\section{Effects of nitrogen on leaf area per plant and chlorophyll of sorghum}

The results in Table 1 show that the leaves area per plant was the largest in the loose powder period and the smallest in maturity period. The leaf area per plant of the N0 treatment was significantly lower than that of other treatments. In 2016, the leaf area per plant of N200 treatment were significantly higher than that of N100 treatment. From the beginning of the grain filling stage, the leaf area per plant of the N200 treatment was significantly higher than that of other treatments, and there was no significant difference between the N100 and N300 treatments. In 2017, there was no significant difference of the leaf area per plant of the nitrogen application treatment in the jointing stage and the grain filling stage, the leaf area per plant of the N300 and N200 treatments in the loose powder period were significantly higher than that of the N100 treatment.

Table 1. Effect of nitrogen on the leaf area per plant

\begin{tabular}{c|c|c|c|c|c|c}
\hline \multirow{2}{*}{ Years } & \multirow{2}{*}{ Treatments } & \multicolumn{6}{|c}{ Leaf area per plant $\left.\mathbf{( c m}^{\mathbf{2}}\right)$} \\
\cline { 3 - 7 } & & Jointing stage & Flag leaf stage & $\begin{array}{c}\text { Loose powder } \\
\text { stage }\end{array}$ & $\begin{array}{c}\text { Grain filling } \\
\text { stage }\end{array}$ & $\begin{array}{c}\text { Wax maturity } \\
\text { stage }\end{array}$ \\
\hline \multirow{4}{*}{2016} & N0 & $1830.11 \pm 37.65 \mathrm{c}$ & $2078.61 \pm 16.50 \mathrm{c}$ & $2234.27 \pm 39.12 \mathrm{c}$ & $1994.95 \pm 43.67 \mathrm{c}$ & $1484.96 \pm 25.53 \mathrm{c}$ \\
& N100 & $2273.24 \pm 46.41 \mathrm{~b}$ & $2458.95 \pm 51.36 \mathrm{~b}$ & $2506.60 \pm 50.36 \mathrm{~b}$ & $2414.66 \pm 50.09 \mathrm{~b}$ & $1827.45 \pm 45.56 \mathrm{~b}$ \\
& N200 & $2433.48 \pm 60.62 \mathrm{a}$ & $2590.64 \pm 16.97 \mathrm{a}$ & $2674.68 \pm 42.52 \mathrm{a}$ & $2631.50 \pm 41.53 \mathrm{a}$ & $1960.99 \pm 48.98 \mathrm{a}$ \\
& $\mathrm{N} 300$ & $2475.86 \pm 29.89 \mathrm{a}$ & $2499.38 \pm 22.83 \mathrm{ab}$ & $2588.37 \pm 36.80 \mathrm{ab}$ & $2497.75 \pm 10.48 \mathrm{~b}$ & $1815.59 \pm 22.22 \mathrm{~b}$ \\
\hline \multirow{3}{*}{2017} & N0 & $1934.98 \pm 72.29 \mathrm{~b}$ & $2110.66 \pm 46.06 \mathrm{c}$ & $2291.26 \pm 22.45 \mathrm{c}$ & $2138.35 \pm 62.95 \mathrm{~b}$ & $1645.66 \pm 22.43 \mathrm{c}$ \\
& N100 & $2484.13 \pm 15.93 \mathrm{a}$ & $2541.70 \pm 21.55 \mathrm{~b}$ & $2706.80 \pm 14.15 \mathrm{~b}$ & $2616.15 \pm 49.27 \mathrm{a}$ & $1937.31 \pm 28.43 \mathrm{a}$ \\
& $\mathrm{N} 200$ & $2549.97 \pm 30.85 \mathrm{a}$ & $2607.04 \pm 4.35 \mathrm{ab}$ & $2809.66 \pm 13.52 \mathrm{a}$ & $2714.87 \pm 28.16 \mathrm{a}$ & $2012.43 \pm 23.06 \mathrm{a}$ \\
& $\mathrm{N} 300$ & $2554.78 \pm 24.59 \mathrm{a}$ & $2643.73 \pm 23.66 \mathrm{a}$ & $2812.57 \pm 26.50 \mathrm{a}$ & $2689.15 \pm 25.80 \mathrm{a}$ & $1813.26 \pm 45.57 \mathrm{~b}$ \\
\hline
\end{tabular}

Mean \pm standard deviation. Values sharing same letters differ non-significantly $(\mathrm{P} \leq 0.05)$

The analysis of Table 2 shows the chlorophyll content of Keza 15 first increased and then decreased with the development of the growth period, and the NO treatment was significantly lower than the nitrogen treatment. There was no significant difference of the chlorophyll content between N200 and N300 except for the grain filling stage in 2017. The chlorophyll content increased with the increase in the nitrogen application, But the increase of chlorophyll content was not more significant than in N200 treatment.

Table 2. Effect of nitrogen on chlorophyll content

\begin{tabular}{c|c|c|c|c|c|c}
\hline \multirow{2}{*}{ Years } & \multirow{2}{*}{ Treatments } & \multicolumn{5}{|c}{ Chlorophyll content (mg/g) } \\
\cline { 3 - 7 } & & Jointing stage & Flag leaf stage & $\begin{array}{c}\text { Loose powder } \\
\text { stage }\end{array}$ & $\begin{array}{c}\text { Grain filling } \\
\text { stage }\end{array}$ & $\begin{array}{c}\text { Wax maturity } \\
\text { stage }\end{array}$ \\
\hline \multirow{3}{*}{2016} & N0 & $3.40 \pm 0.21 \mathrm{~b}$ & $3.98 \pm 0.05 \mathrm{~b}$ & $4.15 \pm 0.05 \mathrm{~b}$ & $3.94 \pm 0.04 \mathrm{c}$ & $1.66 \pm 0.04 \mathrm{~b}$ \\
& N100 & $4.93 \pm 0.04 \mathrm{a}$ & $5.05 \pm 0.03 \mathrm{a}$ & $5.22 \pm 0.05 \mathrm{a}$ & $4.30 \pm 0.02 \mathrm{~b}$ & $2.54 \pm 0.02 \mathrm{a}$ \\
& N200 & $5.10 \pm 0.07 \mathrm{a}$ & $5.13 \pm 0.06 \mathrm{a}$ & $5.31 \pm 0.03 \mathrm{a}$ & $4.57 \pm 0.06 \mathrm{a}$ & $2.59 \pm 0.01 \mathrm{a}$ \\
& N300 & $5.14 \pm 0.06 \mathrm{a}$ & $5.17 \pm 0.04 \mathrm{a}$ & $5.25 \pm 0.04 \mathrm{a}$ & $4.52 \pm 0.04 \mathrm{a}$ & $2.61 \pm 0.03 \mathrm{a}$ \\
\hline \multirow{3}{*}{2017} & N0 & $4.04 \pm 0.11 \mathrm{~b}$ & $4.16 \pm 0.03 \mathrm{c}$ & $4.28 \pm 0.06 \mathrm{~b}$ & $3.26 \pm 0.04 \mathrm{~d}$ & $1.64 \pm 0.02 \mathrm{c}$ \\
& N100 & $5.12 \pm 0.05 \mathrm{a}$ & $5.25 \pm 0.03 \mathrm{~b}$ & $5.69 \pm 0.03 \mathrm{a}$ & $4.36 \pm 0.03 \mathrm{c}$ & $2.63 \pm 0.01 \mathrm{~b}$ \\
& N200 & $5.15 \pm 0.04 \mathrm{a}$ & $5.44 \pm 0.04 \mathrm{a}$ & $5.63 \pm 0.04 \mathrm{a}$ & $4.70 \pm 0.02 \mathrm{a}$ & $2.72 \pm 0.03 \mathrm{a}$ \\
& N300 & $5.13 \pm 0.06 \mathrm{a}$ & $5.42 \pm 0.01 \mathrm{a}$ & $5.63 \pm 0.05 \mathrm{a}$ & $4.57 \pm 0.03 \mathrm{~b}$ & $2.72 \pm 0.02 \mathrm{a}$ \\
\hline
\end{tabular}

Mean \pm standard deviation. Values sharing same letters differ non-significantly $(\mathrm{P} \leq 0.05)$ 


\section{Effects of nitrogen on the activity of NR, GOGAT, GS, GLDH in high density sorghum}

It can be seen from Figure 3 that NR activity increases with the increase of nitrogen application, and the nitrogen application treatment in seedling stage is significantly higher than that in non-nitrogen application treatment. From flag picking stage to the end of grouting, there is a significant difference between the four nitrogen treatments. In the early stage of grouting, the activity reaches the peak, the lowest in seedling stage, and the N300 treatment in mature stage is significantly higher than that in N0 and N100.
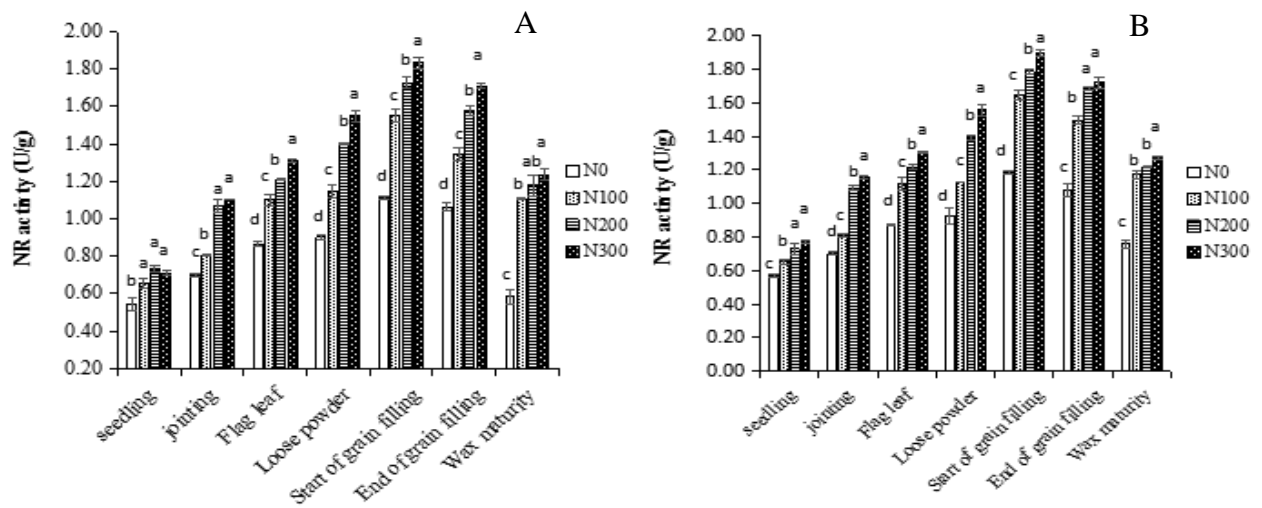

Figure 3. Effect of nitrogen on NR activity of sorghum leaf (A) 2016, (B) 2017. Different letters indicate different means, according to LSD test $(p<0.05)$

It can be seen from Figure 4 that there was no significant difference in activity of GOGAT among the nitrogen application treatments in the seedling stage, jointing stage and wax mature stage in 2016; there was a significant difference among the treatments in the flag leaf stage; there was no significant difference between the N200 and N300 treatments from the powder stage to the late filling stage, and there was a significant increase in the N200 and N300 treatments compared with the other nitrogen treatments. In 2017, the activity of GOGAT between the N200 and N300 treatments have no significant difference in the jointing stage, late grain filling stage and max maturity stage, but it was significantly higher than in the N0 and N100 treatments; the N300 treatment in the flag leaf stage and loose powder stage was significantly higher than other treatments.
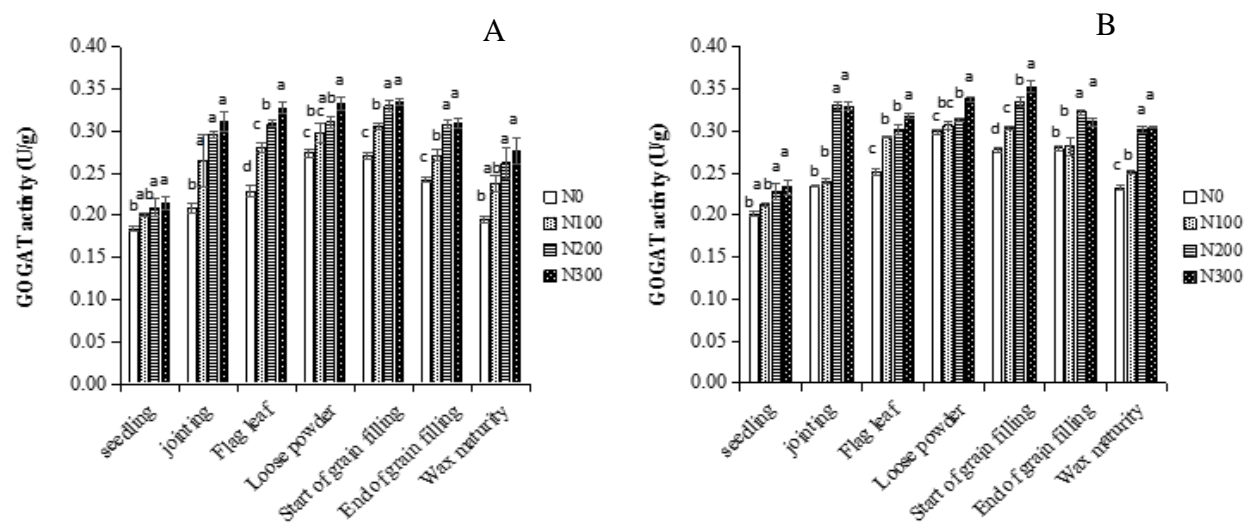

Figure 4. Effect of nitrogen on GOGAT activity of sorghum leaf (A) 2016, (B) 2017. Different letters indicate different means, according to LSD test $(p<0.05)$ 
It can be seen from Figure 5 that with the increase in the nitrogen level, GS activity increased. In 2016, the N100, N200, and N300 treatments were significantly higher than the N0 treatment except for the seeding stage, and N200, and N300 had no significant difference among the nitrogen treatments except the seedling stage, jointing stage, start of grain filling stage. From the jointing stage, the GS activity of N300 was significantly higher than that of N100. In 2017, the GS activity of the N200 and N300 treatments showed no significant difference in the seedling stage, powder stage and wax maturity stage, but it was significantly higher than in the N0 and N100 treatments. The GS activity of the N300 treatment was the highest and that of the N0 treatment was the lowest.
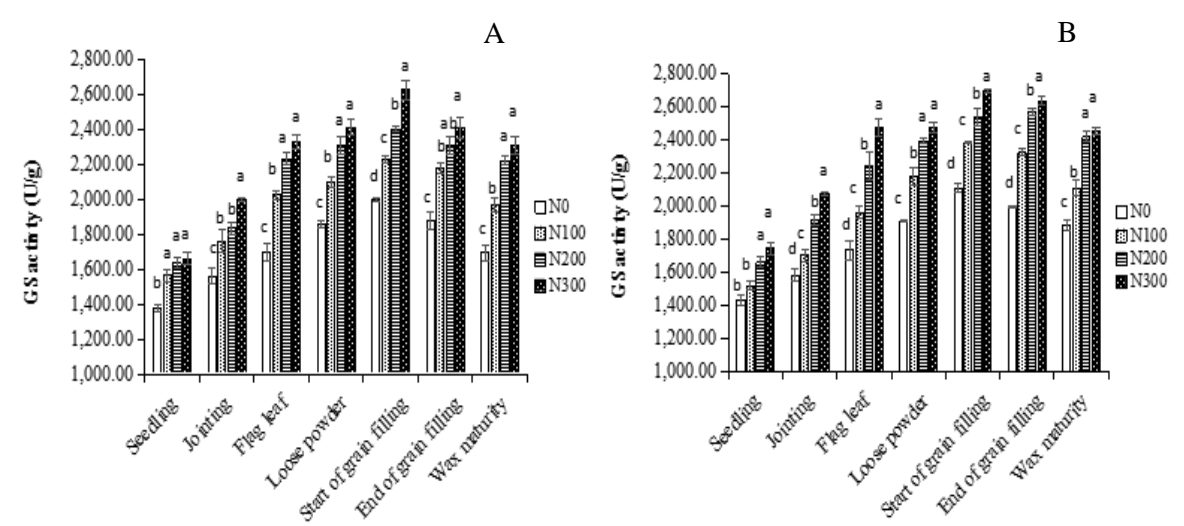

Figure 5. Effect of nitrogen on GS activity of sorghum leaf (A) 2016, (B) 2017. Different letters indicate different means, according to LSD test ( $p<0.05)$

It can be seen from Figure 6 that the activity of GLDH N200 and N300 were significantly higher than that of the N0 treatment. In 2016, the activity of GLDH in the N300 treatment was significantly higher than the other treatments in the jointing stage and early filling stage. The activity of GLDH showed no significant difference between the N200 treatment and the N100 and N300 treatments in the loose powder stage and late filling stage, which were significantly higher than those in the N0 treatment. In 2017, the activity of GLDH in the N300 treatment was significantly higher than in the other treatments. The activity of GLDH showed no significant difference between the N0 and N100 treatments in the powder stage but decreased significantly compared with other treatments. The activity of GLDH in the N200 and N300 were significantly higher than in other treatments at the early filling and wax stages.

\section{Effect of nitrogen on yield and quality}

The analysis of Table 3 shows that in a certain range, the grain weight per ear of sorghum increased with the increase in nitrogen application, but when the nitrogen level exceeded that of the N200 treatment, the grain number per ear no longer continued to increase and began to decline, the change trend is the same as the yield. The 1000-grain weight of the N0 treatment was significantly lower than that of the N100, N200 and N300 treatments, but there was no significant difference between the N100, N200 and N300 treatments.

The effect of nitrogen on sorghum protein increased with the increase in nitrogen application, and there was no significant difference between N200 and N300. It can be seen from the experiment that the effect of nitrogen on protein was the same in different years. 

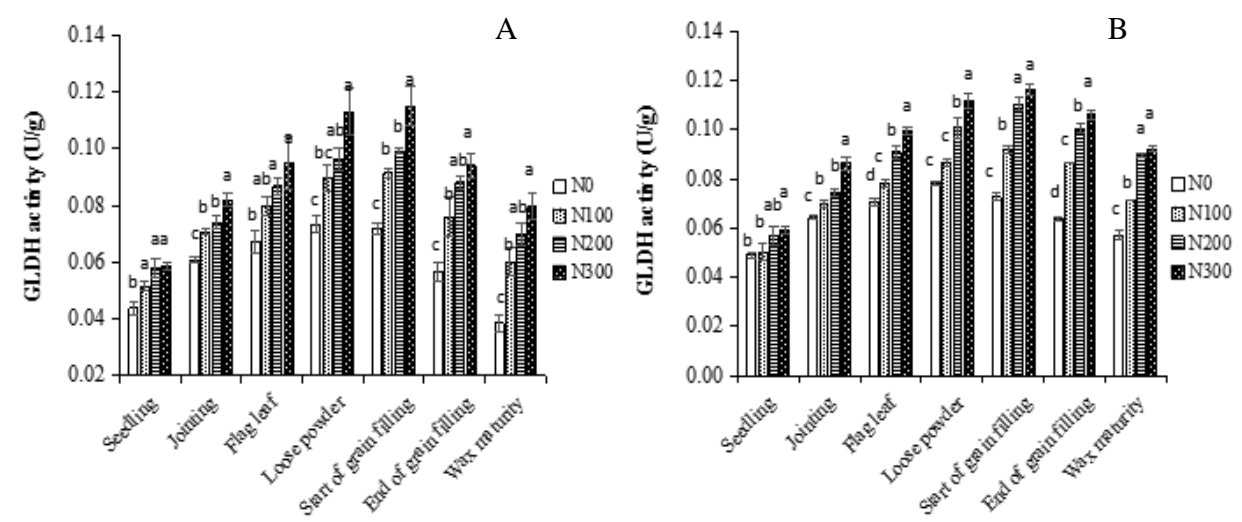

Figure 6. Effect of nitrogen on GLDH activity of sorghum leaf (A) 2016, (B) 2017. Different letters indicate different means, according to LSD test $(p<0.05)$

Table 3. Effect of nitrogen level on yield and protein accumulation of sorghum

\begin{tabular}{|c|c|c|c|c|c|}
\hline Years & Treatments & $\begin{array}{c}\text { Protein } \\
\text { accumulation } \\
\left(\mathrm{mg} \cdot \text { grain }^{-1}\right)\end{array}$ & $\begin{array}{c}\text { The grain } \\
\text { number per ear } \\
\text { (Li) }\end{array}$ & $\begin{array}{l}\text { Thousand grain } \\
\text { weight (g) }\end{array}$ & Yield $\left(\mathrm{kg} / \mathrm{hm}^{2}\right)$ \\
\hline \multirow{4}{*}{2016} & N0 & $1.20 \pm 0.01 \mathrm{c}$ & $1009.00 \pm 6.00 \mathrm{c}$ & $20.44 \pm 0.35 b$ & $6186.40 \pm 118.89 \mathrm{c}$ \\
\hline & N100 & $2.57 \pm 0.05 b$ & $1066.00 \pm 11.36 \mathrm{~b}$ & $24.30 \pm 0.24 \mathrm{a}$ & $7770.63 \pm 27.76 b$ \\
\hline & N200 & $2.95 \pm 0.05 \mathrm{a}$ & $1104.70 \pm 4.91 \mathrm{a}$ & $24.53 \pm 0.24 \mathrm{a}$ & $8128.30 \pm 95.85 a$ \\
\hline & N300 & $2.96 \pm 0.06 \mathrm{a}$ & $1069.00 \pm 11.68 b$ & $24.15 \pm 0.36 \mathrm{a}$ & $7742.43 \pm 97.39 b$ \\
\hline \multirow{4}{*}{2017} & No & $1.42 \pm 0.02 c$ & $1018.00 \pm 10.21 b$ & $20.34 \pm 0.45 b$ & $6210.82 \pm 75.92 \mathrm{c}$ \\
\hline & N100 & $1.82 \pm 0.02 b$ & $1087.70 \pm 16.41 \mathrm{a}$ & $25.37 \pm 0.58 \mathrm{a}$ & $8278.23 \pm 61.97 \mathrm{a}$ \\
\hline & N200 & $2.11 \pm 0.09 \mathrm{a}$ & $1069.30 \pm 6.39 \mathrm{a}$ & $25.76 \pm 0.58 \mathrm{a}$ & $8262.74 \pm 89.85 a$ \\
\hline & N300 & $2.27 \pm 0.06 \mathrm{a}$ & $1002.00 \pm 4.51 \mathrm{~b}$ & $25.28 \pm 0.41 \mathrm{a}$ & $7600.17 \pm 64.28 \mathrm{~b}$ \\
\hline
\end{tabular}

Mean \pm standard deviation. Values sharing same letters differ non-significantly $(\mathrm{P} \leq 0.05)$

\section{Correlation analysis of enzyme activity, leaf area per plant, chlorophyll content with yield and quality}

To find out the relationship between the effects of nitrogen on the physiological and biochemical characters of leaves and the yield and protein of sorghum correlation analysis was carried out. The analysis of Table 4 shows that the chlorophyll content and leaf area of a single plant were significantly positively correlated with the yield and protein content in different growth periods, and the correlation coefficient is above 0.900. The activity of NR, GOGAT, GS, GLDH NR was positively correlated with protein content for two years.

There was no significant correlation between NR activity and yield at jointing stage and loose powder stage in 2017, but there was a significant positive correlation between NR activity and yield at other stages, and the correlation coefficient was the largest at wax ripening stage. GOGAT activity showed a significant correlation with production in 2016 but showed no significant correlation with production in 2017. GS activity was positively correlated with yield in 2016 , there was no significant correlation between the jointing stage in 2017. GLDH content had a significant correlation with yield in 20162017, with the largest correlation coefficient in the grouting period. 
Table 4. Correlation of enzyme activity, leaf area per plant, chlorophyll content with yield and quality

\begin{tabular}{|c|c|c|c|c|c|c|c|c|c|c|c|}
\hline \multirow{2}{*}{ Years } & \multirow{2}{*}{ Project } & \multicolumn{2}{|c|}{ Jointing stage } & \multicolumn{2}{|c|}{ Flag leaf stage } & \multicolumn{2}{|c|}{ Loose powder stage } & \multicolumn{2}{|c|}{ Grain filling stage } & \multicolumn{2}{|c|}{ Wax maturity stage } \\
\hline & & Yield & Protein & Yield & Protein & Yield & Protein & Yield & Protein & Yield & Protein \\
\hline \multirow{6}{*}{2016} & Chlorophyll & $0.938^{* *}$ & $0.957^{* *}$ & $0.950^{* *}$ & $0.977^{* *}$ & $0.973^{* *}$ & $0.981^{* *}$ & $0.902^{* *}$ & $0.936^{* *}$ & $0.960^{* *}$ & $0.975^{* *}$ \\
\hline & Leaf area & $0.926^{* *}$ & $0.941^{* *}$ & $0.963^{* *}$ & $0.976^{* *}$ & $0.914^{* *}$ & $0.919^{* *}$ & $0.956^{* *}$ & $0.957^{* *}$ & $0.908^{* *}$ & $0.939^{* *}$ \\
\hline & NR & $0.760^{* *}$ & $0.812^{* *}$ & $0.848^{* *}$ & $0.896^{* *}$ & $0.787^{* *}$ & $0.838^{* *}$ & $0.810^{* *}$ & $0.866^{* *}$ & $0.943^{* *}$ & $0.961^{* *}$ \\
\hline & GOGAT & $0.750^{* *}$ & $0.813^{* *}$ & $0.861^{* *}$ & $0.890^{* *}$ & $0.632^{*}$ & $0.711^{* *}$ & $0.821^{* *}$ & $0.867^{* *}$ & $0.801^{* *}$ & $0.811^{* *}$ \\
\hline & GS & $0.733^{* *}$ & $0.787^{* *}$ & $0.843^{* *}$ & $0.886^{* *}$ & $0.792^{* *}$ & $0.854^{* *}$ & $0.832^{* *}$ & $0.871^{* *}$ & $0.811^{* *}$ & $0.862^{* *}$ \\
\hline & GLDH & $0.747^{* *}$ & $0.804^{* *}$ & $0.674^{*}$ & $0.688^{*}$ & $0.633^{*}$ & $0.702^{*}$ & $0.805^{* *}$ & $0.829^{* *}$ & $0.778^{* *}$ & $0.846^{* *}$ \\
\hline \multirow{6}{*}{2017} & Chlorophyll & $0.932^{* *}$ & $0.811^{* *}$ & $0.900^{* *}$ & $0.883^{* *}$ & $0.929^{* *}$ & $0.810^{* *}$ & $0.902^{* *}$ & $0.898^{* *}$ & $0.920^{* *}$ & $0.866^{* *}$ \\
\hline & Leaf area & $0.880^{* *}$ & $0.832^{* *}$ & $0.869^{* *}$ & $0.907^{* *}$ & $0.879^{* *}$ & $0.903^{* *}$ & $0.871^{* *}$ & $0.841^{* *}$ & $0.923^{* *}$ & $0.609^{*}$ \\
\hline & NR & 0.539 & $0.948^{* *}$ & $0.726^{* *}$ & $0.938^{* *}$ & 0.566 & $0.926^{* *}$ & $0.803^{* *}$ & $0.930^{* *}$ & $0.864^{* *}$ & $0.899^{* *}$ \\
\hline & GOGAT & 0.442 & $0.871^{* *}$ & $0.745^{* *}$ & $0.922^{* *}$ & 0.293 & $0.780^{* *}$ & 0.426 & $0.721^{* *}$ & 0.562 & $0.914^{* *}$ \\
\hline & GS & 0.487 & $0.926^{* *}$ & 0.51 & $0.897^{* *}$ & $0.684^{*}$ & $0.942^{* *}$ & $0.726^{* *}$ & $0.984^{* *}$ & $0.655^{*}$ & $0.951^{* *}$ \\
\hline & GLDH & 0.371 & $0.808^{* *}$ & 0.482 & $0.883^{* *}$ & 0.469 & $0.898^{* *}$ & $0.730^{* *}$ & $0.974^{* *}$ & $0.653^{*}$ & $0.952^{* *}$ \\
\hline
\end{tabular}

$\mathrm{ns}$, no significance; $* \mathrm{p} \leq 0.05 ; * * \mathrm{p} \leq 0.01$

\section{Discussion}

Nitrogen utilization is an important physiological activity in plant growth and development. Chlorophyll content, leaf area index, regulation of enzymes have a great impact on nitrogen absorption and utilization (Worku et al., 2012). Leaf senescence and its chlorophyll content, and photoassimilates distribution, affect crop yield and are important parameters that should be evaluated in plant growth and crop yield improvement studies (Ronga et al., 2015; Mosisa and Habtamu, 2007). If too much nitrogen is transported to the grain too early, the nitrogen content in the leaves will be reduced, and the photosynthesis of the plant will be affected, which will lead to a reduction of crop yield (Mi et al., 2012).

It can be seen from the analysis of this experiment that under the condition of dense planting, the leaf area and chlorophyll content of sorghum increased with the increase of nitrogen fertilizer and reached the peak value under N200 treatment. The leaf area and chlorophyll content of N200 and N300 treatments were significantly higher than that of N0 and N100 treatments from jointing stage to loose powder stage, which indicated that the higher nitrogen treatment in this period was beneficial to leaf area and chlorophyll content. The leaf area of N300 treatment was lower than that of N200 treatment (Table 1) from the filling grain stage to the wax mature stage. We analyzed that the growth of N300 leaves, and plants was too vigorous, resulting in poor ventilation, the lower leaves could not receive light radiation, resulting in yellowing and wilting under the condition of high density. It may also be due to excessive nitrogen nutrition, resulting in blocked physiological metabolism. From the filling stage to the waxing stage, the chlorophyll content of N200 and N300 was significantly higher than that of N0 and N100 (Table 2), which indicated that the higher nitrogen level after the filling grain stage was beneficial to the chlorophyll content of dwarf sorghum. Table 4 analysis shows that leaf area and chlorophyll content were significantly correlated with yield and protein, and the correlation coefficient was the largest from loose powder stage to filling stage, indicating that leaf area and chlorophyll content will play a positive role in yield and quality of dwarf sorghum in this period. 
The increase in nitrogen application can promote the activities of NR and GS, the ability of nitrogen absorption and assimilation after flowering, and the content of grain protein (Wang et al., 2002). The activities of enzymes related to leaf nitrogen metabolism are directly affected by the level of soil fertilizer supply (Tischner, 2000). The appropriate amount of nitrogen fertilizer can improve the activities of NR, GS, GOGAT and GLDH in the leaves of maize at the later stage of growth, but excessive application of nitrogen fertilizer will reduce their activities (Zhang et al., 2002; Liu et al., 2007; Geng et al., 2009; Li et al., 2018). In this study, the activities of NR, GS, GLDH and GOGAT in sorghum leaves were significantly reduced by low nitrogen treatment, ranked as N300 > N200 > N100 > N0, indicating that the activities increased with the increase in nitrogen.

The highest value of NR activity in the early stage of grain filling was $103.97 \%$, $137.02 \%, 135.79 \%$ and $157.95 \%$ higher than the lowest value of nitrogen treatments in the seedling stage in 2016, and 106.82\%, 151.92\%, $144.93 \%$ and $147.02 \%$ higher in 2017. The results showed that lower nitrogen significantly reduced NR activity and the extent of the increase range. The GS activity of Keza15 reached the peak value in the early stage of grain filling, and the difference between the N300 and N0 treatments was $27.78 \%$. Although the activities of GOGAT and GLDH were positively correlated with nitrogen, there were significant differences between the years.

The activity of NR, NIR and GOGAT decreased from flag leaf stage to grain filling stage, while the activity of GS remained stable or even increased, which may be related to the important function of GS in the process of nitrogen reuse (Zheng, 2009; Lea et al., 2003) It was found that the activities of NR, GOGAT, GS and GLDH were kept at a high level from the flag leaf stage to the filling grain stage, and there was no trend of decline, indicating that the application of enzyme activity to nitrogen of dwarf sorghum lasted for a long time.

Increasing nitrogen fertilizer can improve the accumulation of photosynthetic products, improve the use of light energy by sorghum (Wang et al., 2015; Zhou et al., 2016). A suitable amount of nitrogen fertilizer is the key to obtain high yield, high benefit and high nitrogen use efficiency (Liang et al., 2017). The results of the study showed that the yield of sorghum increased first and then decreased with the increase in nitrogen application. The yield of the NO treatment was significantly lower than that of nitrogen application treatments. Although nitrogen improved the yield of sorghum, too much nitrogen was harmful to the yield of sorghum. When nitrogen exceeded N200, the number of grains per ear no longer continued to increase and began to decrease, change trend and significance are the same as yield change. However, there was no significant difference in 1000 grain weight among different nitrogen treatments. The results showed that the correlation between the yield of sorghum and the number of grains per ear was more significant than that of 1000 grains under the condition of dense planting.

Our research showed that not only leaf area and chlorophyll are important factors to improve yield and quality of high-density planting dwarf sorghum, but also enzyme activity related to nitrogen metabolism is one of the important reasons for high yield. The higher the activity of nitrogen metabolism related enzymes, the stronger the ability of nitrogen assimilation, the more chlorophyll and photosynthetic related enzymes can be synthesized to improve the yield and quality. The higher enzyme activity, green leaf area and chlorophyll content from the filling grain stage to the wax mature stage will play an important role in the formation of yield, which can be used as a reference index for high yield of dwarf sorghum. 


\section{Conclusion}

Leaf area, chlorophyll content, the activity of NR and GS were the most significant correlation between yield and protein content of dwarf sorghum. The loose powder stage to grain filling stage was an important period for yield and quality formation. The yield of dwarf sorghum was mainly determined by the number of grains per ear, $200 \mathrm{~kg}$ of nitrogen $\mathrm{ha}^{-1}$ was the most beneficial to yield and protein of dwarf sorghum. It will be our research goal to study the mechanism of nitrogen metabolism of dwarf sorghum under high-density planting condition.

Acknowledgements. This work was supported by the China Agriculture Research System (CARS-06135-A17)

\section{REFERENCES}

[1] Beevers, L., Hageman, R. (1969): Nitrate reduction in higher plants. - Annual Review of Plant Physiology 20: 495-522.

[2] Bingham, I. J., Karley, A. J., White, P. J., Thomas, W. T., Russell, J. R. (2012): Analysis of improvements in nitrogen use efficiency associated with 75 years of barley breeding. European Journal of Agronomy 42: 49-58.

[3] Chow, F., Pedersén, M., Oliveira, M. C. (2013): Modulation of nitrate reductase activity by photosynthetic electron transport chain and nitric oxide balance in the red macroalga Gracilaria chilensis (Gracilariales, Rhodophyta). - Journal of Applied Phycology 25(6): 1847-1853.

[4] Geng, Y. H., Li, G., Cao, X. Y. (2009): Effect of different nutrition levels of nitrogen and potassium on ammonia metabolism of spring maize. - Journal of Maize Science 17(6): $101-104$

[5] Giagnoni, L., Pastorelli, R., Mocali, S., Arenella, M., Nannipieri, P., Renella, G. (2016): Availability of different nitrogen forms changes the microbial communities and enzyme activities in the rhizosphere of maize lines with different nitrogen use efficiency. Applied Soil Ecology 98: 30-38.

[6] Gou, W., Zheng, P. F., Tian, L., Gao, W., Zhang, L. X., Akram, N. A., Ashraf, M. (2017): Exogenous application of urea and a urease inhibitor improves drought stress tolerance in maize (Zea mays L.). - Journal of Plant Research 130(3): 599-609.

[7] Han, S. F., Li, S. W., Wu, L. Q., Wen, H. D., Xiao, K. (2007): Responses and corresponding physiological mechanisms of different wheat varieties in their nitrogen efficiency and nitrogen uptake to nitrogen supply. - Applied Ecology 18(4): 807-812.

[8] Jin, L.; Cui, H.; Li, B.; Zhang, J. W.; Dong, S. T.; Liu, P. (2012): Effects of integrated agronomic management practices on yield and nitrogen efficiency of summer maize in North China. - Field Crop Research 134: 30-35.

[9] Kaur, G., Asthir, B., Bains, N., Farooq, M. (2015): Nitrogen nutrition, its assimilation and remobilization in diverse wheat genotypes. - International Journal Agriculture \& Biology 17: 531-538.

[10] Khripach, V., Zhabinskii, V., Groot, A. (2000): Twenty years of brassinosteroids: steroidal plant hormones warrant better crops for the XXI century. - Annals of Botany 86(3): 441-447.

[11] Lea, P. J., Miflin, B. J. (2003): Glutamate synthase and the synthesis of glutamate in plants. - Plant Physiology and Biochemistry 41(6): 555-564.

[12] Li, W. L., Lv, Y. J., Liu, X. M., Tong, T., Cao, X. B., Gu, W. R., Wei, S. (2018): Effects of nitrogen fertilizer on nitrogen metabolizing enzymes, nitrogen utilization and yield of 
maize with different nitrogen efficiency. - Southwest China Journal of Agricultural Sciences 31: 1829-1835.

[13] Liang, X. H., Liu, J., Cao, X. (2017): Effect of nitrogen application on yield and nitrogen utilization of brewing sorghum. - Acta Agriculturae Boreali-Sinica 32(2): 179-184.

[14] Liu, S. Y., Dong, S. T., Zhao, B. Q., Li, X. Y., Zhang, Z. S. (2007): Effects of long-term fertilization on key enzyme activities of nitrogen metabolism in summer maize leaves. Trans. Chin. Acta Agronomica Sinica 33(2): 278-283.

[15] Lu, W. J., Zhang, S. H., Guo, C. J., Duan, W. W., Xiao, K. (2009): Studies on the physiological parameters related to nitrogen use efficiency in wheat cultivars with different nitrogen utilization. - Plant Nutrition and Fertilizer Science 15(5): 985-991.

[16] Mi, G. H., Chen, F. J., Yuan, L. X. (2012): Physiological mechanism of nitrogen regulation on young ear and grain development of maize. - Soil and Crops 4: 193-198.

[17] Mosisa, W., Habtamu, Z. (2007): Advances in improving harvest index and grain yield of maize in Ethiopia. - East African Journal Sciences 1(2): 112-119.

[18] Nath, M., Tuteja, N. (2016): NPKS uptake, sensing, and signaling and mi RNAs in plant nutrient stress. - Protoplasma 253: 767-786.

[19] Presterl, T., Groh, S., Landbeck, M., Seitz, G., Schmidt, W., Geiger, H. H. (2010): Nitrogen uptake and utilization efficiency of European maize hybrids developed under conditions of low and high nitrogen input. - Plant Breeding 121(6): 480-486.

[20] Ronga, D., Lovelli, S., Zaccardelli, M., Perrone, D., Ulrici, A., Francia, E., Milc, J., Pecchioni, N. (2015): Physiological responses of processing tomato in organic and conventional Mediterranean cropping systems. - Scientia Horticulturae 190: 161-172.

[21] Ronga, D., Caradonia, F., Setti, L., Hagassou, D., Giaretta Azevedo, C. V., Milc, J., Pedrazzi, S., Allesina, G., Arru, L., Francia, E. (2019): Effects of innovative biofertilizers on yield of processing tomato cultivated in organic cropping systems in northern Italy. Acta Horticulturae 1233: 129-136.

[22] Shen, H. J., Yang, S. R., Yang, G. Y., Shan, D. P., Tang, M., Sun, Z. H., Chen, L., Wang, F. M. (2013): Standardized cultivation techniques of dwarf sorghum Suiza7. - China Seed Industry 10: 57-58.

[23] Singaram, P., Kamalakumari, K. (2000): Effect of continuous manuring and fertilisation on maize grain quality and nutrient soil enzyme relationship. - Madras Agriculture 86(7): 51-54.

[24] Singletary, G. W., Doehlert, D. C., Wilson, C. M., Muhitch, M. J., Below, F. E. (1990): Response of enzymes and storage proteins of maize endosperm to nitrogen supply. Plant Physiology 94(3): 858-864.

[25] Tilman, D., Balzer, C., Hill, J., Befort, B. L. (2011): Global food demand and the sustainable intensification of agriculture. - Proceedings of the National Academy of Science of America 108(50): 20260-20264.

[26] Tischner, R. (2000): Nitrate uptake and reduction in higher and lower plants. - Plant Cell \& Environment 23(10): 1015-1024.

[27] Wang, X. K. (2006): Principles and Techniques of Plant Physiology and Biochemistry Experiments. - Higher Education Press, Beijing.

[28] Wang, Y. F., Yu, Z. W., Li, S. X., Yu, S. L. (2002): Effect of nitrogen nutrition level on the activity of key enzymes of nitrogen metabolism and the content of egg self quality in winter wheat. - Acta Agronomica Sinica 28(6): 743-748.

[29] Wang, L. M., Jiao, S. J., Jiang, Y. X. (2011): Breeding and cultival technique of food sorghum new variety hybrid Longza13. - Seed of China 30(9): 12-15.

[30] Wang, J. S., Jiao, X. Y., Ding, Y. C., Dong, E. W., Bai, W. B., Wang, L. G., Wu, A. L. (2015): Response of grain sorghum nutrient absorption, yield and quality to nitrogen, phosphorus and potassium nutrition. - Acta Agronomica Sinica 41(8): 1269-1278.

[31] Worku, M., Bänziger, M., Friesen, D., Diallo, A. O., Horst, W. J. (2012): Nitrogen efficiency as related to dry matter partitioning and root system size in tropical mid- 
altitude maize hybrids under different levels of nitrogen stress. - Field Crops Research 130: 57-67.

[32] Xiong, S. P., Wu, K. Y., Wang, X. C., Zhang, J., Du, P., Wu, Y. X., Ma, X. M. (2016): Analysis of root absorption characteristics and nitrogen utilization of wheat genotypes with different N efficiency. - Scientia Agricultura Sinica 49(12): 2267-2279.

[33] Yamaya, T., Obara, M., Nakajima, H., Sasaki, S., Hayakaha, T., Sato, T. (2002): Genetic manipulation and quantitative-trait loci mapping for nitrogen recycling in rice. - Journal of Experimental Botany 53(370): 917-925.

[34] Yang, G. D., Hu, Z. Y., Liu, L. L., Chen, L. Q. (2015): Cultivation techniques of sorghum in the north of Heilongjiang Province. - Heilongjiang Agricultural Sciences 5: 165-166.

[35] Zeng, J. M., Cui, K. H., Huang, J. L., He, F., Peng, S. B. (2007): Responses of physiobiochemical properties to $\mathrm{N}$-fertilizer application and its relationship with nitrogen use efficiency in rice (Oryza sativa L.). - Acta Agronomica Sinica 33(7): 1168-1176.

[36] Zhang, J. W., Wang, K. J., Hu, C. H., Dong, S. T., Liu, P. (2002): Effect of nitrogen application period on Forage Nutrition Value of summer maize. - Scientia Agricultura Sinica 3: 1337-1342.

[37] Zheng, Z. L. (2009): Carbon and nitrogen nutrient balance signaling in plants. - Plant Signaling \& Behavior 4(7): 584-591.

[38] Zhou, L. B., Wang, C., Lu, X. J., Zhang, G. B., Xu, Y., Wu, L. Y., Shao, M. B. (2016): Effects of fertilization and planting density on photosynthetic characteristics, agronomic characteristics and yield of nuo sorghum qg7. - Journal of Southern Agriculture 47(5): 644-648. 